\title{
Intermolecular Coupling of the Allenyl Ligand on Tungsten to form Hexa-1,5-diene aided by Triosmium Clusters
}

\author{
Ming-Chou Chen, Rai-Shing Keng, Ying-Chih Lin,* Yu Wang, Ming-Chu Cheng, and Gene-Hsiang Lee \\ Department of Chemistry, National Taiwan University, Taipei, Taiwan 10764, ROC
}

The propynyl ligand of the trimethyl phosphite substituted tungsten complex $\left[\left(\eta^{5}-\mathrm{C}_{5} \mathrm{H}_{5}\right) \mathrm{W}(\mathrm{CO})_{2}\left\{\mathrm{P}(\mathrm{OMe})_{3}\right\}\left(\mathrm{CH}_{2} \mathrm{C} \equiv \mathrm{CH}\right)\right]$ is converted to an allenyl ligand at room temperature and the reaction of $\left[\left(\eta^{5}-\mathrm{C}_{5} \mathrm{H}_{5}\right) \mathrm{W}(\mathrm{CO})_{3}\left(\mathrm{CH}=\mathrm{C}=\mathrm{CH}_{2}\right)\right]$ with $\left[\mathrm{H}_{2} \mathrm{Os}_{3}(\mathrm{CO})_{10}\right]$ yields the coupling product $\left[\mathrm{H}_{2} \mathrm{Os}_{6}\left(\mathrm{CO}_{20}\left(\mathrm{C}_{6} \mathrm{H}_{8}\right)\right](4)\right.$; the structure of $(4)$, established by $X$-ray crystallography, confirms the presence of a hexa-1,5-diene ligand with two alkene groups bound to two triosmium clusters in a $\mu, \eta^{2}$-fashion.

The use of stoicheiometric reagents for carbon-carbon bond formation is a promising synthetic method. Particular attention has been given to research on $\pi$-allyl ligands in nickel complexes; e.g., hexa-1,5-diene formation or formation of ketones by $\mathrm{CO}$ insertion during coupling. ${ }^{1-3}$ However, the alternative $\sigma$-bonding mode of the allenyl ligand in metal complexes has been studied in relatively few cases. ${ }^{4-6} \mathrm{We}$ recently reported that the reaction of an allenyl tungster complex and the iron methylene complex $\left[\mathrm{Fe}_{2}(\mathrm{CO})_{8}\left(\mathrm{CH}_{2}\right)\right.$ yields a tungsten-substituted trimethylenemethane iron com 


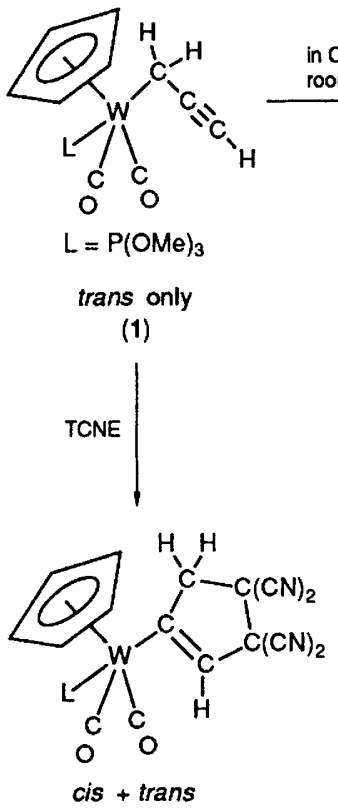

(3)

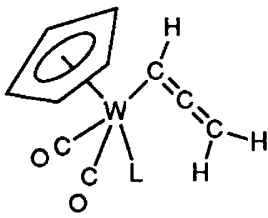

cis + trans

(2)

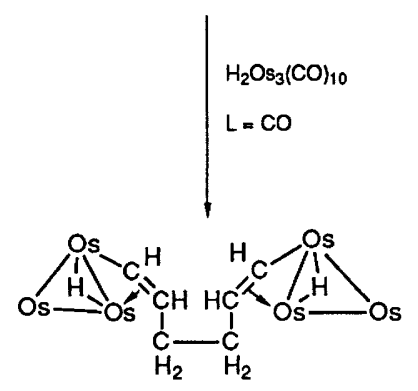

(4) plex. ${ }^{7}$ To understand further the mechanism of the formation of the $\sigma$-allenyl ligand, and its chemical reactivity, we report herein the preparation of the phosphite-substituted tungsten propynyl complex $\left[\left(\eta^{5}-\mathrm{Cp}\right) \mathrm{W}(\mathrm{CO})_{2}\left\{\mathrm{P}(\mathrm{OMe})_{3}\right\}\left(\mathrm{CH}_{2} \mathrm{C} \equiv \mathrm{CH}\right)\right]$ (1) $(\mathrm{Cp}=$ cyclopentadienyl $)$, its transformation to the allenyl complex $\left[\left(\eta^{5}-\mathrm{Cp}\right) \mathrm{W}(\mathrm{CO})_{2}\left\{\mathrm{P}(\mathrm{OMe})_{3}\right\}\left(\mathrm{CH}=\mathrm{C}=\mathrm{CH}_{2}\right)\right](2)$, and the reaction of $\left[\mathrm{H}_{2} \mathrm{Os}_{3}(\mathrm{CO})_{10}\right]$ with $\left[\left(\eta^{5}-\mathrm{Cp}\right) \mathrm{W}(\mathrm{CO})_{3^{-}}\right.$ $\left(\mathrm{CH}=\mathrm{C}=\mathrm{CH}_{2}\right)$ ] to yield, to the best of our knowledge, the first example of an allenyl coupled product.

The trans- and cis-phosphite-substituted tungsten propynyl complexes $\left[\left(\eta^{5}-\mathrm{Cp}\right) \mathrm{W}(\mathrm{CO})_{2}\left\{\mathrm{P}(\mathrm{OMe})_{3}\right\}\left(\mathrm{CH}_{2} \mathrm{C} \equiv \mathrm{CH}\right)\right](\mathbf{1}), \dagger$ in

† Spectroscopic data: trans-(1): ${ }^{1} \mathrm{H}$ NMR $\left(\mathrm{C}_{2} \mathrm{D}_{6} \mathrm{CO}\right): \delta 5.27(\mathrm{~d}, 5 \mathrm{H}$, $\left.\mathrm{Cp}, J_{\mathrm{P}-\mathrm{H}} 1.5 \mathrm{~Hz}\right), 3.60\left[\mathrm{~d}, 9 \mathrm{H}, \mathrm{P}(\mathrm{OMe})_{3}, J_{\mathrm{P}-\mathrm{H}} 11.7 \mathrm{~Hz}\right], 1.75(\mathrm{dd}, 2 \mathrm{H}$, $\left.\mathrm{CH}_{2}, J_{\mathrm{P}-\mathrm{H}} 4.1, J_{\mathrm{H}-\mathrm{H}} 2.8 \mathrm{~Hz}\right)$, and $2.08\left(\mathrm{t}, 1 \mathrm{H}, J_{\mathrm{H}-\mathrm{H}} 2.8 \mathrm{~Hz}\right) ;{ }^{13} \mathrm{C}$ NMR $\left(\mathrm{C}_{6} \mathrm{D}_{6}\right): \delta 226.3\left(\mathrm{~d}, J_{\mathrm{C}-\mathrm{P}} 25 \mathrm{~Hz}, 2 \mathrm{CO}\right) 95.5(\mathrm{~s}, \equiv \mathrm{C}-\mathrm{C}), 91.1(\mathrm{~s}, \mathrm{Cp}), 65.8$ $(\mathrm{s}, \equiv \mathrm{C}-\mathrm{H}), 52.5\left(\mathrm{~d}, J_{\mathrm{C}-\mathrm{P}} 3.8 \mathrm{~Hz}, \mathrm{OMe}\right)$, and $-33.0\left(\mathrm{~d}, J_{\mathrm{C}-\mathrm{P}} 11.6 \mathrm{~Hz}\right.$, W-CH $) ;{ }^{31} \mathrm{P}$ NMR $\left(\mathrm{C}_{2} \mathrm{D}_{6} \mathrm{CO}\right): 160.7\left(J_{\mathrm{W}-\mathrm{P}} 384.7 \mathrm{~Hz}\right) ; v_{\mathrm{CO}}\left(\mathrm{CHCl}_{3}\right)$ : $1941 \mathrm{~m}$, and $1854 \mathrm{~s} \mathrm{~cm}^{-1} ; \mathrm{m} / \mathrm{z} 470\left(M^{+}, 186 \mathrm{~W}\right), 431\left(M^{+}-\mathrm{C}_{3} \mathrm{H}_{3}\right), 414$ $\left(M^{+}-2 \mathrm{CO}\right)$, and $346\left[M^{+}-\mathrm{P}(\mathrm{OMe})_{3}\right]$.

cis-(1): ${ }^{1} \mathrm{H}$ NMR $\left(\mathrm{C}_{2} \mathrm{D}_{6} \mathrm{CO}\right): \delta 5.46(\mathrm{~s}, 5 \mathrm{H}, \mathrm{Cp}), 3.60[\mathrm{~d}, 9 \mathrm{H}$, $\left.\mathrm{P}(\mathrm{OMe})_{3}, J_{\mathrm{P}-\mathrm{H}} 11.8 \mathrm{~Hz}\right], 2.12\left(\mathrm{td}, 1 \mathrm{H}, \mathrm{CH}, J_{\mathrm{P}-\mathrm{H}} 0.6, J_{\mathrm{H}-\mathrm{H}} 2.9 \mathrm{~Hz}\right), 1.59$ $\left(\mathrm{dd}, 1 \mathrm{H}, J_{\mathrm{P}-\mathrm{H}} 8.3, J_{\mathrm{H}-\mathrm{H}} 2.9 \mathrm{~Hz}\right)$, and $1.54\left(\mathrm{dd}, 1 \mathrm{H}, J_{\mathrm{P}-\mathrm{H}} 7.9, J_{\mathrm{H}-\mathrm{H}} 2.9\right.$ $\mathrm{Hz}) ;{ }^{31} \mathrm{P}$ NMR $\left(\mathrm{C}_{2} \mathrm{D}_{6} \mathrm{CO}\right): 152.1\left(J_{\mathrm{W} \cdot \mathrm{P}} 474.7 \mathrm{~Hz}\right)$.

trans-(2): ${ }^{1} \mathrm{H}$ NMR $\left(\mathrm{CDCl}_{3}\right): \delta 6.01\left(\mathrm{dt}, 1 \mathrm{H}, \mathrm{CH}, J_{\mathrm{P}-\mathrm{H}} 2.8, J_{\mathrm{H}-\mathrm{H}} 6.5\right.$ $\mathrm{Hz}), 4.78\left(\mathrm{~d}, 5 \mathrm{H}, \mathrm{Cp}, J_{\mathrm{P}-\mathrm{H}} 1.5 \mathrm{~Hz}\right), 4.26\left(\mathrm{dd}, 2 \mathrm{H}, \mathrm{CH}_{2}, J_{\mathrm{P}-\mathrm{H}} 2.1, J_{\mathrm{H}-\mathrm{H}}\right.$ $6.5 \mathrm{~Hz})$, and $3.23\left[\mathrm{~d}, 9 \mathrm{H}, \mathrm{P}(\mathrm{OMe})_{3}, J_{\mathrm{P}-\mathrm{H}} 11.5 \mathrm{~Hz}\right.$.

cis-(2): ${ }^{1} \mathrm{H}$ NMR $\left(\mathrm{CDCl}_{3}\right): \delta 5.68\left(\mathrm{dt}, 2 \mathrm{H}, \mathrm{CH}, J_{\mathrm{P}-\mathrm{H}} 13.8, J_{\mathrm{H}-\mathrm{H}} 6.6\right.$ $\mathrm{Hz}), 4.87(\mathrm{~s}, 5 \mathrm{H}, \mathrm{Cp}), 4.09\left(\mathrm{dd}, 2 \mathrm{H}, \mathrm{CH}_{2}, J_{\mathrm{P}-\mathrm{H}} 2.0, J_{\mathrm{H}-\mathrm{H}} 6.6 \mathrm{~Hz}\right), 4.06$ $\left(\mathrm{dd}, 2 \mathrm{H}, \mathrm{CH}_{2}, J_{\mathrm{P}-\mathrm{H}} 2.0, J_{\mathrm{H}-\mathrm{H}} 6.6 \mathrm{~Hz}\right)$, and $3.23\left[\mathrm{~d}, 9 \mathrm{H}, \mathrm{P}(\mathrm{OMe})_{3}, J_{\mathrm{P}-\mathrm{H}}\right.$ $11.5 \mathrm{~Hz}$.

trans- $(3):{ }^{1} \mathrm{H} \mathrm{NMR}\left(\mathrm{CDCl}_{3}\right): \delta 5.10\left(\mathrm{t}, 1 \mathrm{H}, \mathrm{CH}, J_{\mathrm{H}-\mathrm{H}} 1.6 \mathrm{~Hz}\right), 4.51$ $\left(\mathrm{d}, 5 \mathrm{H}, \mathrm{Cp}, J_{\mathrm{P}-\mathrm{H}} 1.4 \mathrm{~Hz}\right), 3.15\left(\mathrm{~d}, 2 \mathrm{H}, \mathrm{CH}_{2}, J_{\mathrm{H}-\mathrm{H}} 1.6 \mathrm{~Hz}\right)$, and 3.08 [d, $9 \mathrm{H}, \mathrm{P}(\mathrm{OMe})_{3}, J_{\mathrm{P}-\mathrm{H}} 11.5 \mathrm{~Hz}$ ); ${ }^{13} \mathrm{C} \mathrm{NMR}\left(\mathrm{C}_{2} \mathrm{D}_{6} \mathrm{CO}\right): 225.3$ (d, $J_{\mathrm{C}-\mathrm{P}} 29.5$ $\mathrm{Hz}, 2 \times \mathrm{CO}), 152.7\left(\mathrm{~d}, J_{\mathrm{C}-\mathrm{P}} 5 \mathrm{~Hz}, \mathrm{~W}-\mathrm{C}\right), 124.2\left(\mathrm{~d}, J_{\mathrm{C}-\mathrm{P}} 1.5 \mathrm{~Hz},=\mathrm{CH}\right)$, $111.8,110.8(4 \times \mathrm{CN}), 90.7(\mathrm{~s}, \mathrm{Cp}), 59.6\left(\mathrm{~d}, J_{\mathrm{C}-\mathrm{P}} 1.7 \mathrm{~Hz}, \mathrm{CH}_{2}\right), 53.4$ $\left(\mathrm{d}, J_{\mathrm{C}-\mathrm{P}} 6.5 \mathrm{~Hz}, \mathrm{POMe}_{3}\right), 51.0,45.6\left[\mathrm{~s}, 2 \mathrm{C}(\mathrm{CN})_{2}\right] ;{ }^{31} \mathrm{P}$ NMR $\left(\mathrm{C}_{6} \mathrm{D}_{6}\right)$ : $152.7\left(J_{\mathrm{W}-\mathrm{P}} 351.3 \mathrm{~Hz}\right) ; v_{\mathrm{CO}}\left(\mathrm{CHCl}_{3}\right): 1957 \mathrm{~m}$ and $1973 \mathrm{~s} \mathrm{~cm}^{-1} ; \mathrm{m} / \mathrm{z} 598$ $\left(M^{+}\right), 570\left(M^{+}-\mathrm{CO}\right), 542\left(M^{+}-2 \mathrm{CO}\right), 442,\left(M^{+}-\mathrm{CO}-\mathrm{L}\right)$, and 414 $\left(M^{+}-2 \mathrm{CO}-\mathrm{L}\right)$.

cis-(3): ${ }^{1} \mathrm{H}$ NMR $\left(\mathrm{CDCl}_{3}\right): \delta 4.68\left(\mathrm{t}, 1 \mathrm{H}, \mathrm{CH}, J_{\mathrm{H}-\mathrm{H}} 1.6 \mathrm{~Hz}\right), 4.55(\mathrm{~s}$, $5 \mathrm{H}, \mathrm{Cp}), 2.57\left(\mathrm{~d}, 2 \mathrm{H}, \mathrm{CH}_{2}, J_{\mathrm{H}-\mathrm{H}} 1.6 \mathrm{~Hz}\right)$, and $3.55\left[\mathrm{~d}, 9 \mathrm{H}, \mathrm{P}(\mathrm{OMe})_{3}\right.$, $\left.J_{\mathrm{P}-\mathrm{H}} 12.6 \mathrm{~Hz}\right] ;{ }^{31} \mathrm{P}$ NMR $\left(\mathrm{C}_{6} \mathrm{D}_{6}\right): 140.2$.

(4): $v_{\mathrm{CO}}\left(\mathrm{C}_{2} \mathrm{Cl}_{4}\right): 2100 \mathrm{w}, 2081 \mathrm{~m}, 2071 \mathrm{~m}, 2059 \mathrm{~s}, 2052 \mathrm{~s}, 2021 \mathrm{~s}, 2011 \mathrm{~s}$, 2003s $1998 \mathrm{~m}, \mathrm{sh}, 1987 \mathrm{w}, \mathrm{sh})$, and $1975 \mathrm{w} \mathrm{cm}^{-1}$.

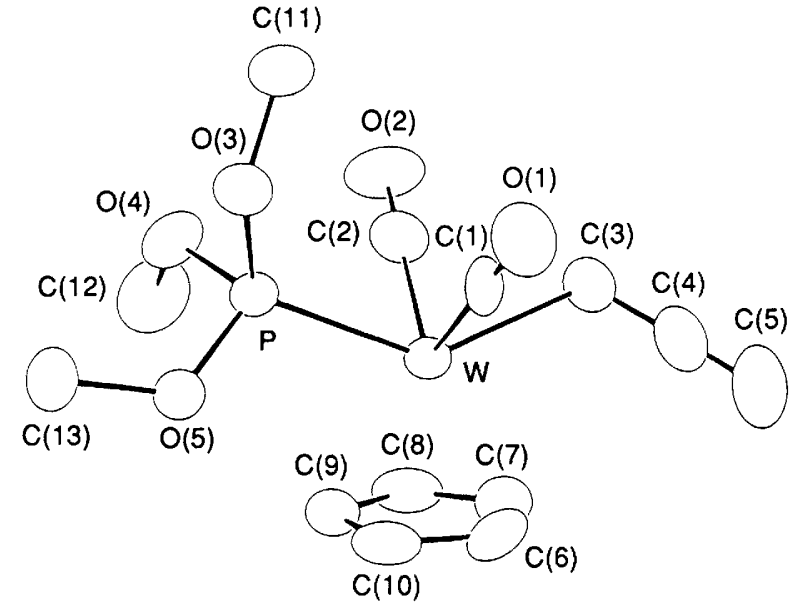

Figure 1. Molecular structure of $\left[(\mathrm{Cp}) \mathrm{W}(\mathrm{CO})_{2}\left\{\mathrm{P}(\mathrm{OMe})_{3}\right\}\left(\mathrm{C}_{3} \mathrm{H}_{3}\right)\right]$ (1). Important bond lengths $(\AA)$ and bond angles $\left({ }^{\circ}\right)$ : W-P, $2.385(2)$; W-C(1), 1.955(5); W-C(2), 1.958(6); W-C(3), 2.348(6); C(3)-C(4), $1.428(10) ; \mathrm{C}(4)-\mathrm{C}(5), 1.174(11)$. C(3)-C(4)-C(5), 178.9(7); P-WC(1), 79.93(16); P-W-C(2), 78.80(19); P-W-C(3), 137.78(16).

Table 1. P-H Coupling constants $(J / \mathrm{Hz})$ in (1), (2), and (3).

\begin{tabular}{cllllll} 
& \multicolumn{2}{c}{$(\mathbf{1})$} & \multicolumn{2}{c}{$(\mathbf{2})$} & $(3)$ \\
Compound & $\mathrm{Cp}$ & $\alpha-\mathrm{CH}_{2}$ & $\mathrm{Cp}$ & $\alpha-\mathrm{CH}$ & $\mathrm{Cp}$ \\
trans & 1.5 & 4.1 & 1.5 & 2.8 & 1.4 \\
cis & 0 & 8.3 & 0 & 13.8 & 0
\end{tabular}

a $12: 1$ ratio, were prepared by the reaction of prop-2-ynyl bromide with $\left[\left(\eta^{5}-\mathrm{Cp}\right)(\mathrm{CO})_{2}\left\{\mathrm{P}(\mathrm{OMe})_{3}\right\} \mathrm{W}\right]^{-}$. The anion was prepared by the reduction of the mercury derivative of the tungsten dimer $\left[\left\{\left(\eta^{5}-\mathrm{Cp}\right)(\mathrm{CO})_{2}\left\{\mathrm{P}(\mathrm{OMe})_{3}\right\} \mathrm{W}\right\}_{2} \mathrm{Hg}\right] .^{8}$ The trans-isomer of complex (1), isolated by recrystallization, was converted to a cis-and trans-isomeric mixture $(3: 1)$ of the allenyl complex $\left[\left(\eta^{5}-\mathrm{Cp}\right) \mathrm{W}(\mathrm{CO})_{2}\left\{\mathrm{P}(\mathrm{OMe})_{3}\right\}\left(\mathrm{CH}=\mathrm{C}=\mathrm{CH}_{2}\right)\right]$ (2) in a relatively high NMR yield (Scheme 1). The fact that a single trans-isomer is transformed to trans- and cis-isomers provides further evidence that such a transformation may proceed through tungsten migration instead of a 1,3 hydrogen shift. ${ }^{9}$ In the corresponding non-phosphite substituted complex, such a transformation has been observed, ${ }^{7}$ at a faster rate. From the rate constant of the transformation, the 1,3 hydrogen shift pathway is unlikely. ${ }^{10}$

For complex trans-(1), the $\mathrm{Cp}{ }^{1} \mathrm{H}$ NMR signal is a doublet with $J_{\mathrm{H}(\mathrm{Cp})-\mathrm{P}} 1.5 \mathrm{~Hz}$, and the $\alpha$ proton shows a relatively small coupling constant, $J_{\mathrm{H}-\mathrm{P}} 4.1 \mathrm{~Hz}$. In contrast, the $\mathrm{Cp}$ resonance of trans-(1) shows the correct configuration. $\neq$ The molecular structure and selected metrical data are presented in Figure 1. of trans-(1) shows the correct configuration. The molecular structure and selected metrical data are presented in Figure 1. The geometry around the tungsten is typical for a piano stool complex. The structural assignments of the cis- and transisomers of (2) are based on their NMR data; in the

$\$$ Crystal data for (1): $\mathrm{C}_{13} \mathrm{H}_{17} \mathrm{O}_{5} \mathrm{PW}, M=468.1, a=8.092(3), b=$ 9.721(1), $c=11.222(6) \AA, \alpha=98.38(3), \beta=97.77(4), \gamma=114.33(2)^{\circ}$, $V=776.9(5) \AA^{3}$, space group $P \overline{1}, Z=2, D_{\mathrm{c}}=2.001 \mathrm{~g} \mathrm{~cm}^{-3}, \mu\left(\mathrm{Mo}-K_{\alpha}\right.$ $=7.71 \mathrm{~mm}^{-1}, F(000)=448, \lambda=0.7107 \AA$. The structure was solved by Patterson and Fourier methods. Of the 2741 unique reflections measured, 2508 were considered significant $[I>2 \sigma(I)]$ and used in the refinement with 182 parameters to give $R=0.023$ and $R_{\mathrm{w}}=0.021$; weights were calculated from counting statistics. 


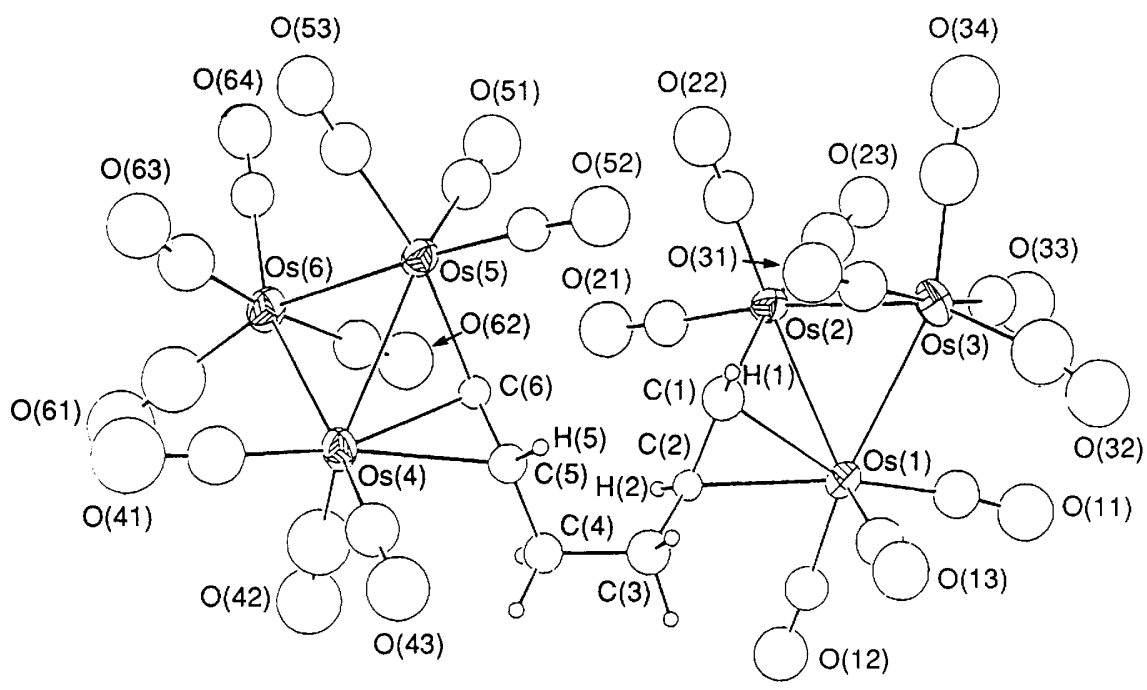

Figure 2. Molecular structure of $\left[\mathrm{H}_{2} \mathrm{Os}_{6}(\mathrm{CO})_{20}\left(\mathrm{C}_{6} \mathrm{H}_{8}\right)\right]$ (4). Important bond lengths $(\AA)$ and bond angles $\left({ }^{\circ}\right)$ : Os $(1)-\mathrm{Os}(2), 2.835(2)$; $\mathrm{Os}(1)-\mathrm{Os}(3), 2.898(2) ; \mathrm{Os}(2)-\mathrm{Os}(3), 2.839(2) ; \mathrm{Os}(4)-\mathrm{Os}(5), 2.834(2) ; \mathrm{Os}(4)-\mathrm{Os}(6), 2.900(2) ; \mathrm{Os}(5)-\mathrm{Os}(6), 2.844(2) ; \mathrm{C}(4)-\mathrm{C}(5), 1.47(5)$; $\mathrm{Os}(2)-\mathrm{C}(1), 2.12(3) ; \mathrm{C}(5)-\mathrm{C}(6), 1.33(4) ; \mathrm{Os}(4)-\mathrm{C}(6), 2.26(3) ; \mathrm{Os}(4)-\mathrm{C}(5), 2.38(3) ; \mathrm{Os}(5)-\mathrm{C}(6), 2.15(3) ; \mathrm{C}(1)-\mathrm{C}(2), 1.37(4) ; \mathrm{C}(2)-\mathrm{C}(3)$, 1.47(4); $\mathrm{C}(3)-\mathrm{C}(4), 1.50(5) . \quad \mathrm{C}(2)-\mathrm{C}(3)-\mathrm{C}(4), 114(3) ; \mathrm{C}(3)-\mathrm{C}(4)-\mathrm{C}(5), 110(3) ; \mathrm{C}(4)-\mathrm{C}(5)-\mathrm{C}(6), 124(3) ; \mathrm{Os}(4)-\mathrm{C}(6)-\mathrm{Os}(5)$, 79.9(10); $\mathrm{Os}(4)-\mathrm{C}(6)-\mathrm{C}(5), 78.4(19) ; \mathrm{Os}(5)-\mathrm{C}(6)-\mathrm{C}(5), 123.3(22) ; \mathrm{Os}(1)-\mathrm{C}(1)-\mathrm{Os}(2), 80.5(12) ; \mathrm{Os}(1)-\mathrm{C}(1)-\mathrm{C}(2), 76.3(20) ; \mathrm{Os}(2)-\mathrm{C}(1)-\mathrm{C}(2), 121.8(24)$; $\mathrm{C}(1)-\mathrm{C}(2)-\mathrm{C}(3), 123(3)$.

trans-isomer, the $\mathrm{Cp}$ resonance is a doublet with $J_{\mathrm{H}(\mathrm{Cp})-\mathrm{P}} 1.5$ $\mathrm{Hz}$ and the coupling constant between the $\mathrm{P}$ and $\alpha$ proton is $2.8 \mathrm{~Hz}$. For the cis-isomer, the $\mathrm{Cp}$ resonance is a singlet and the coupling constant $J_{\mathrm{P}-\mathrm{H} \alpha}$ is $13.8 \mathrm{~Hz}$. Reaction of trans-(1) with tetracyanoethylene (TCNE) also gave the $[3+2]$ cyclization ${ }^{12}$ product $\left[\left(\eta^{5}-\mathrm{Cp}\right) \mathrm{W}(\mathrm{CO})_{2}\left\{\mathrm{P}(\mathrm{OMe})_{3}\right\}\left\{\mathrm{C}_{5} \mathrm{H}_{3}-\right.\right.$ $\left.\left.(\mathrm{CN})_{4}\right\}\right](3)$. Again, such a reaction involves the migration of the $\mathrm{W}$ atom, and therefore the trans- and cis-isomers of complex (3) were both observed in the NMR spectrum.

The non-phosphite substituted tungsten allenyl complex $\left[\left(\eta^{5}-\mathrm{Cp}\right) \mathrm{W}(\mathrm{CO})_{3}\left(\mathrm{CH}=\mathrm{C}=\mathrm{CH}_{2}\right)\right]$ (2a) was treated with $\mathrm{H}_{2} \mathrm{Os}_{3}(\mathrm{CO})_{10}$ at room temperature to yield the coupling product $\left[\mathrm{H}_{2} \mathrm{Os}_{6}(\mathrm{CO})_{20}\left(\mathrm{C}_{6} \mathrm{H}_{8}\right)\right](4)$ after column chromatography. Two allenyl ligands coupled intermolecularly to form a hexa-1,5-diene ligand with two double bonds bound to two triosmium clusters in a $\mu, \eta^{2}$-fashion. Several intermediates were observed when the reaction was carried out in an NMR tube. Identification of these species is currently underway. An $X$-ray crystallographic study established the structure of complex (4) (Figure 2). $\S$ In (4), the two Os atoms attain an 18

$\S$ Crystal data for (4): $\mathrm{C}_{26} \mathrm{H}_{10} \mathrm{O}_{20} \mathrm{Os}_{6}, M=1783.5$, monoclinic, $a=$ $14.448(7), b=13.689(4), c=19.224(4) \AA, \beta=107.14(3)^{\circ}, V=$ $3633(2) \AA^{3}$, space group $P 2_{1} / c, Z=4, D_{\mathrm{c}}=3.257 \mathrm{~g} \mathrm{~cm}^{-3} \mu\left(\mathrm{Mo}-K_{\alpha}\right)=$ $21.0 \mathrm{~mm}^{-1}, F(000)=3119, \lambda=0.7107 \AA$. The structure was solved by Patterson and Fourier methods. Of the 4748 unique reflections measured, 2860 were considered significant $[I>2 \sigma(I)]$ and used in the refinement with 240 parameters to give $R=0.054$ and $R_{\mathrm{w}}=0.048$; weights were calculated from counting statistics. Atomic co-ordinates, bond lengths and angles, and thermal parameters have been deposited at the Cambridge Crystallographic Data Centre. See Notice to Authors, Issue No. 1. electron configuration by co-ordination of two $\mu-\eta^{2}$ unsaturated groups of the newly formed hexa-1,5-diene. The length of the two double bonds in the hexadiene is 133 and $137 \mathrm{pm}$. The alkene protons are in a trans-configuration. Hydride ligands were not located in the difference map and, based on the 18 electron rule, were presumably between the Os metal atoms bridged by the two alkene ligands.

We thank the National Science Council of the Republic of China for financial support.

Received, 20th March 1990; Com. 0/01220C

\section{References}

1 A. J. Pearson, 'Metallo-organic Chemistry,' Wiley, New York, 1983, p. 203.

2 M. Kumada, Pure Appl. Chem., 1980, 52, 669.

3 P. H. Dixneuf, Pure Appl. Chem., 1989, 61, 1763.

4 M. D. Johnson and C. Mayle, Chem. Commun., 1969, 192.

5 A. Wojcicki, Adv. Organomet. Chem., 1974, 12, 31.

6 C. P. Casey and E. A. Austin, J. Am. Chem. Soc., 1988, 110, 7106.

7 R. S. Keng and Y. C. Lin, Organometallics, 1990, 9, 291.

8 M. J. Mays and S. M. Pearson, J. Chem. Soc. A, 1968, 2291.

9 C. W. Spangler, Chem. Ber. 1979, 76, 187.

10 T. Clark, J. Am. Chem. Soc., 1989, 111, 761.

11 K. W. Barnett and P. M. Treichel, Inorg. Chem., 1967, 6, 294.

12 M. Rosenblum, Acct. Chem. Res., 1974, 7, 122. 